\title{
Which Subjects and Styles Have Been Examined in Islamic Fatwas and Guidelines?
}

\section{Apakah Jenis Subjek dan Gaya Yang Telah Dibincangkan Dalam Fatwa dan Garis Panduan Islam?}

\author{
Ishak Ramli ${ }^{1}$, Mumtaz Mokhtar ${ }^{2}$, D’zul Haimi Mohd Zain ${ }^{3}$, Muhamad Rahimi Osman4, \\ Noorman Masrek ${ }^{5}$ \\ ${ }^{1}$ Universiti Teknologi MARA, Cawangan Perak, 32610 Seri Iskandar, Perak, MALAYSIA \\ ${ }^{2345}$ Universiti Teknologi MARA 40450 Shah Alam, Selangor, MALAYSIA \\ Authors'email: ibr_86@yahoo.com¹,mumtazmikhail@gmail.com², dzul@uitm.edu.my ${ }^{3}$, \\ mrahimi313@uitm.edu.my ${ }^{4}$, mnoormanm@gmail.com ${ }^{5}$
}

Published: 7 September 2018

\begin{abstract}
Visual art is one of the most critical and popular issues explored from an Islamic standpoint. This is because the selected subject is prepared in a variety of approaches and ways. Additionally, the shown style creates concerns regarding the legislation and ambiguous perspectives on it. Clearly, no detailed discussion of the range of issues and styles in visual arts was conducted considering recent changes. As such, this article will outline the issues and styles mentioned in the fatwas and guidelines that have been issued. All fatwas and guidelines pertaining to visual arts were found using the process of assembling the highlights of the structured and methodical study. As a result of these observations, only a few categories of subjects have been covered, including humans, animals, plants, religious symbols, and human-made equipment; and the style discussed focuses exclusively on the mode of depiction. Recommendations to researchers interested in this work include conducting extensive qualitative research.
\end{abstract}

Keywords: Fatwa, Subject, Style, and Visual Arts

\begin{abstract}
ABSTRAK
Seni visual antara topik yang hangat dan kritikal yang dibincangkan dari perspektif Islam. Hal ini kerana wujud olahan subjek yang dipilih dilukis dengan pelbagai kaedah dan cara. Selain itu, gaya yang dipamerkan juga menimbulkan persoalan tentang hukum dan pandangan yang tidak jelas terhadapnya. Secara jelas, tiada perbincangan komprehensif yang dijalankan melibatkan kepelbagaian subjek dan gaya dalam seni visual berdasarkan perkembangan semasa. Oleh yang demikian, kertas kerja ini bermatlamat untuk $245 y$ mbol245e dengan terperinci apakah jenis subjek dan gaya yang telah dibincangkan dalam fatwa dan garis panduan yang telah wujud. Berdasarkan kaedah penyusunan sorotan kajian berstruktur dan sistematik, kesemua fatwa dan garis panduan yang berkaitan dengan seni visual dikenalpasti. Berdasarkan pemerhatian tersebut, hasilnya, hanya terdapat beberapa jenis subjek sahaja yang telah dibincangkan iaitu manusia, haiwan, tumbuhan, 245ymbol agama dan peralatan ciptaan manusia; dan gaya yang dibincangkan secara keseluruhan hanyalah pada jenis representasi sahaja. Cadangan kepada penyelidik yang berminat dengan kajian ini haruslah menjalankan penyelidikan secara terperinci dengan menggunakan pendekatan kualitatif.
\end{abstract}

Kata Kunci: Fatwa, Subjek, Gaya, Seni Visual

eISSN: 2550-214X (C) 2018. The Authors. Published for Idealogy Journal of Arts and Social Science by UiTM Press. This is an Open Access article distributed under the terms of the Creative Commons Attribution-NonCommercial-NoDerivatives License (http://creativecommons.org/licenses/by-nc-nd/4.0/), which permits non-commercial re-use, distribution, and reproduction in any medium, provided the original work is properly cited, and is not altered, transformed, or built upon in any way. 


\section{PENGENALAN}

Seni visual merupakan topik perbincangan yang sering mendapat perhatian dari perspektif Islam. Kedudukan seni visual dalam Islam bukanlah sesuatu yang asing malahan telahpun diperbincang sejak dari zaman Nabi Muhamad SAW. Terdapat beberapa kupasan ayat al-Qur'an dan hadith yang memberikan gambaran praktikal seni visual yang sepatutnya diamalkan.

Selain itu, kedudukan seni visual juga telah pun dilihat dari sudut tingkatannya dalam Maqasid Shariah iaitu seni visual berada pada tingkatan menyempurnakan atau melengkapkan (dalam Maqasid shariah dikenali sebagai at- tahsiniyyat) kehidupan manusia (Ishak et al. 2017). Walau bagaimanapun, kedudukan ini perlulah dilihat semula dari pelbagai aspek dalam seni visual seperti: 1) penggunaan subjek dan gaya dalam seni visual; 2) alat dan bahan yang digunakan dalam menghasilkan seni visual; dan 3) proses jual-beli artifak seni visual berdasarkan perjanjian, imej yang dipamerkan dan prinsip pemilikan harta dalam Islam. Perbincangan seni visual dalam kontek Maqasid shariah perlulah diperhalusi dari aspek yang dinyatakan diatas kerana ditakuti akan merosakkan kelangsungan kehidupan didunia dan keselamatan hidup diakhirat (dalam Maqasid Shariah dikenali sebagai addharuriyyat) (Abdul Aziz, 2012).

Terdapat beberapa penyelidikan yang dilihat mengutarakan dan mempersoalkan tentang kepentingan penyelidikan terhadap seni visual menurut pandangan Islam (Sulaiman Esa, 1997; D'zul Haimi, 1997; Khatijah, 2000; Ahmadrashidi, 2010; Nor Azlin, 2012; Wan Samiati, 2017). Penyelidikan mereka adalah berkaitan pertembungan seni terhadap social order di Malaysia yang melibatkan Islam (Sulaiman, 1997), perbandingan iluminasi al-Qur'an zaman Safavid (D'zul Haimi, 1997), perbincangan implikasi Islam terhadap pendidikan seni visual di Malaysia (Khatijah, 2000), pola perkembangan seni visual dari konteks seni catan Islam kontemporari di Malaysia (Ahmadrashidi, 2010), perbincangan penggunaan kaligrafi dalam seni kontemporari di Malaysia (Nor Azlin, 2012) dan perbincangan axiology atau nilai dalam sejumlah karya dalam pameran kesenian Islam di Malaysia (Wan Samiati, 2017). Mereka ada membincangkan secara umum tentang amalan kesenian haruslah mengambilkira soal kepatuhan terhadap Shariah. Namun begitu, penyelidikan saintifik yang dikhususkan mengkaji seni visual berdasarkan pandangan dan penelitian Shariah Islam masih tidak dijalankan.

Dalam tesis Nor Azlin Hamidon (2012) mempersoalkan tentang adakah wujud garis panduan berkaitan etika dalam penghasilan seni visual berdasarkan undang-undang Islam. Beliau mengutarakan permasalahan dalam seni visual adalah kekurangan perbincangan yang bersiafat saintifik melalui pandangan Islam dan kelaziman dalam kebudayaan Melayu. Walau bagaimanapun, persoalan yang diutarakan Nor Azlin dilihat memiliki jurang penyelidikan kerana kajian yang dijalankan adalah berkaitan seni kaligrafi Islam yang wujud di Malaysia. Persoalan berkaitan garis panduan dan etika dalam Islam masih tidak diselesaikan.

Dalam pada itu, wujudnya terminologi yang dilihat sejajar dengan penyelidikan ini tetapi berbeza maksud dan matlamatnya iaitu seni Islam (artifak seni yang dihasilkan berdasarkan manifestasi tawhid, al-Qur'an dan Hadith yang kebiasaannya seni arabesque) dan seni Muslim (artifak seni yang dihasilkan oleh seniman yang beragama Islam). Hal ini telah mewujudkan percanggahan dan pertikaian seperti: 1) Seni Islam - adakah tepat digelar seni Islam pada artifak seni arabesque yang dihasilkan oleh orang bukan Islam?; 2) Seni Muslim - adakah sesuai digelar seni Muslim jika imej dan bentukkan artifak yang dihasilkan melanggar kepatuhan Islam oleh seniman Muslim? Hal ini akan merosakkan nama dan kesucian Islam dan gelaran Muslim itu sendiri.

Dalam penyelidikan ini, penyelidik cenderung memfokuskan kepada jenis- jenis subjek dan gaya dalam seni visual yang dibenarkan dalam Shariah Islam (penyelidik tidak membincangkan a] penggunaan alatan dan bahan dalam seni visual menurut perspektif Islam; dan b] proses jual-beli artifak seni visual menurut pandangan Islam). Hal ini kerana persekitaran seni visual di Malaysia yang bersifat pluralis (Muliyadi, 2001) yang menggabungkan beberapa elemen seperti: 1) subjek yang bersifat realistic berlatarkan dekorasi seni Islam (arabesque); 2) mengabstraksikan subjek rujukan 
menggunakan gaya Barat; 3) perletakkan symbol agama Islam sejajar dengan symbol agama lain; dan sebagainya.

Oleh yang demikian, penyelidikan ini bermatlamat untuk mengkaji tentang kewujudan fatwa-fatwa dan garis panduan terhadap seni visual. Matlamat ini dikhususkan berkaitan apakah jenis subjek dan gaya dalam seni visual yang telah dibincangkan dalam fatwa dan garispanduan yang telah wujud. Seterusnya, penyelidik akan mengenalpasti jurang penyelidikan yang wujud dalam seni visual menurut pandangan Shariah Islam.

\section{PERBINCANGAN SUBJEK DAN GAYA DALAM SENI VISUAL}

Dalam penyelidikan ini tertumpu kepada perbincangan seni visual dan hukum Islam terhadapnya. Oleh yang demikian, topik ini akan menerangkan kepelbagaian subjek dan gaya dalam seni visual; fatwa dan garis panduan yang telah wujud terhadap seni visual; dan gap dalam perbincangan hukum Islam berdasarkan kepelbagaian subjek dan gaya.

\subsection{Subjek dalam Seni Visual}

Perbincangan jenis subjek dalam seni visual kurang diselidiki secara sistematik. Hal ini kerana kebiasaan penyelidikan yang dijalankan adalah berkaitan dengan persoalan isu, psikologi, bentuk, makna, teori dan falsafah. Namun begitu, penerangan secara umum tentang kepelbagaian subjek yang digunakan ada dikupas secara ringkas oleh Ahmad J. Pauline (1983) dan Muliyadi (2005).

Ahmad (1983) mengkategorikan subjek kepada: 1) subjek peribadi - imej yang memiliki emosi yang mempengaruhi audien; 2) subjek bukan peribadi - imej yang tidak memiliki emosi dan tidak mempengaruhi audien; 3) subjek landskap - imej pokok, gunung dan lain-lain; 4) subjek pemandangan bandar atau townscape - imej bandar, bangunan dan kehidupan bandar; dan 5) subjek harian atau stilllife - imej buah-buahan, bunga dan lain-lain.

Manakala Muliyadi mengkategorikan subjek dalam seni visual terbahagi kepada hal figura (manusia dan haiwan), alam semulajadi dan persekitaran serta objek-objek buatan manusia. Pembahagian Ahmad tentang subjek harian dan landskap jelas berada dibawah kategori alam semulajadi. Bagi subjek townscape berada dibawah kategori campuran diantara objek-objek buatan manusia dan manusia (jika terdapat imej manusia didalamnya).

Sedikit persamaan seperti yang dibincangkan Alimuddin (2007) namun mengkategorikan subjek kepada dua bahagian utama iaitu subjek bernyawa dan tidak bernyawa. Pembahagian Alimuddin ini dilihat sering digunakan dalam penetapan hukum bagi permasalahan dalam seni visual menurut pandangan Islam. Ishak et al. (2017) menjelaskan pernyataan Alimuddin dengan mengaitkan pandangan Sidi Gazalba (Asyari, 2012) berkaitan subjek bernyawa terbahagi kepada manusia dan haiwan. Manakala tidak bernyawa adalah berkaitan alam semulajadi dan objek-objek buatan manusia (sama seperti pengkategorian yang dibuat oleh Muliyadi, 2005). Selain itu, Ishak et al. (2017) menyatakan terdapat subjek yang digabungkan didalam proses penghasilan karya seperti: 1) gabungan manusia dengan manusia; 2) gabungan manusia dengan haiwan; 3) gabungan manusia dengan alam semulajadi; 4) gabungan manusia dengan objek buatan manusia; 5); gabungan haiwan dengan haiwan 6) gabungan haiwan dengan alam semulajadi; 7) gabungan haiwan dengan objek buatan manusia; 8) gabungan alam semulajadi dengan alam semulajadi; 9) gabungan alam semulajadi dengan objek buatan manusia; dan 10) gabungan objek buatan manusia dengan objek buatan manusia. Keseluruhan gabungan diantara subjek ini digelar sebagai hybrid subject.

Oleh yang demikian, pengkategorian kepelbagaian subjek dalam seni visual adalah seperti berikut: 1) manusia; 2) haiwan; 3 ) alam semulajadi; 4) objek-objek buatan manusia; dan 5) hybrid subject. 


\subsection{Gaya dalam Seni Visual}

Kewujudan gaya dalam seni visual sering dibincangkan dalam banyak penyelidikan. Pengenalpastian gaya yang diutarakan dalam artifak dapat menampilkan aliran seni yang cuba dipaparkan. Persoalan gaya sering dilihat dari beberapa kontek seperti: 1) gaya seniman; dan 2) persamaan gaya diantara seniman. Gaya seniman sering dikaitkan dengan kemampuan mengekspresi dalam proses penghasilan karya seni visual (Ocvirk et al. 2006). Perbandingan diantara hasil karya seniman yang berbeza mewujudkan kepelbagaian gaya yang dihasilkan.

Hasilnya, melalui penyelidikan lepas menunjukkan kepelbagaian gaya tersebut dapat dikategorikan kepada beberapa jenis seperti gaya imitation, representasi, naturalistic, objektif, formal order, emotion, realistic, denaturalisasi, stailisasi, semi-abstrak dan abstraksi (Ahmad J. Pauline, 1983; D'zul Haimi, 2000; Muliyadi, 2005; Abu Talib, 2005; D'zul Haimi, 2006; Ocvirk et al. 2006; Muliyadi, 2012; D'zul Haimi, 2012; Ishak et al. 2017; Wan Samiati, 2017). Namun begitu, secara keseluruhan terdapat tiga kategori yang dilihat lebih tepat kerana memiliki persamaan dalam setiap penyelidikan lepas iaitu: 1) representasi; 2) stailisasi; dan 3) abstraksi.

Representasi merupakan satu gaya yang memaparkan atau menggambarkan secara sempurna berdasarkan imej atau subjek yang dirujuk. Makna representasi dilihat sama dengan objective, imitation, naturalistic, dan realistic. Bagi kategori stailisasi bermaksud gambaran subjek yang telah diubah atau dipermudah tetapi masih memiliki karakter subjek yang dirujuk. Makna stailisasi ini sama dengan denaturalisasi dan semi-abstrak. Manakala abstraksi ialah gaya yang dihasilkan berdasarkan rujukan sesuatu subjek tetapi telah melalui proses perubahan keseluruhannya dan tidak dapat dikenalpasti karakter subjek yang dirujuk.

\subsection{Hubungan Subjek dan Gaya dalam Seni Visual}

Dalam penelitian seni visual, hubungan subjek dan gaya adalah sejajar dalam pembinaan hasil karya seni visual. Subjek yang dipilih akan diolah dalam menghasilkan komposisi yang tepat berdasarkan gaya tertentu. Hal ini terjadi berdasarkan keperluan isu yang dipilih, penelitian terhadap subjek yang bersesuaian, pengolahan gaya yang diminati dan kreativiti yang disokong dalam penghasilan karya. visual:

Berikut merupakan pergerakan keperluan subjek dan gaya dalam proses penghasilan karya seni

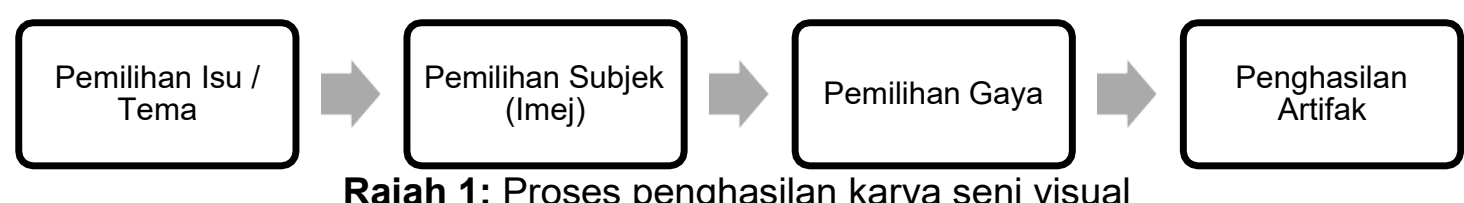

Berdasarkan pentingnya kedudukan pemilihan subjek dan pengolahan gaya ini, penelitian subjek (manusia, haiwan, alam semulajadi dan objek-objek buatan manusia) dalam penghasilan karya akan dibantu oleh pemilihan gaya (representasi, stailisasi dan abstraksi) yang bersesuaian. Namun begitu, pemilihan subjek yang bersesuaian dengan isu haruslah seiring menepati kehendak Islam. Dalam pada itu, gaya yang dipilih seharusnya membantu menyelesaikan permasalahan isu dan membantu mengatasi kepatuhan agama.

Oleh yang demikian, penelitian terhadap hukum yang telah wujud dalam Islam haruslah dilihat semula bagi mengetahui skop seni visual yang telah dibincangkan (Ishak et al. 2017). Selain itu, penambah baikan dapat dilaksanakan bagi memurnikan situasi seni visual yang mematuhi keperluan syariat Islam. 


\section{JENIS SUBJEK DAN GAYA DALAM PENETAPAN HUKUM ISLAM TERHADAP SENI VISUAL}

Dalam permasalahan seni visual, perkara ini telah dibincangkan sejak zaman awal perkembangan Islam. Perbincangan berkaitan seni visual ini terus menjadi perhatian sehingga zaman sekarang. Hal ini berlaku kerana perkembangan media dan teknologi khususnya dalam proses penghasilan gambar menggunakan teknologi kamera menjadi semakin membimbangkan. Tambahan pula, terdapat pelbagai aplikasi dan software yang dapat digunakan untuk menyunting gambar yang dimiliki sesuai dengan kehendak penyunting. Pelbagai usaha dibuat dalam memberi garis panduan dalam menggunakan teknologi yang ada menurut pandangan Islam. Terdapat pelbagai sumber berkaitan dengan fatwa dan garis panduan berkaitan dengan seni visual yang telah digazetkan sebagai rujukan umum. Dalam skop seni visual, kebanyakkan perbincangan dalam garis panduan dan fatwa cenderung menggunakan istilah gambar dan patung (Salman, 2007) atau seni yang dapat dilihat dengan mata (Yusuf al-Qaradhawi, 2001). Oleh yang demikian, skop penyelidikan ini difokuskan kepada permasalahan berkaitan dengan visual. Table 1 indicates the existing guidelines and legislation berkaitan dengan permasalahan dalam visual:

Jadual 1: Jenis subjek dan gaya dalam fatwa dan garis panduan Islam

\begin{tabular}{|c|c|c|c|}
\hline Tajuk & $\begin{array}{c}\text { Jenis } \\
\text { Rujukan }\end{array}$ & $\begin{array}{l}\text { Negeri / } \\
\text { Negara }\end{array}$ & Ringkasan \\
\hline $\begin{array}{l}\text { Garis Panduan } \\
\text { dan Penjelasan } \\
\text { Mengenai Seni } \\
\text { Tampak dari } \\
\text { Kaca Mata } \\
\text { Islam }\end{array}$ & $\begin{array}{c}\text { Garis } \\
\text { Panduan } \\
\text { oleh Jabatan } \\
\text { Kemajuan } \\
\text { Islam } \\
\text { Malaysia } \\
\text { (JAKIM) } \\
(1987)\end{array}$ & Malaysia & $\begin{array}{l}\text { Garis panduan ini menghuraikan hukum } \\
\text { (harus dan haram) dalam seni visual dalam } \\
\text { jenis lukisan (2 dimensi) dan jenis ukiran (3 } \\
\text { Dimensi). Secara keseluruhan, } \\
\text { perbincangan } \\
\text { merangkumi perbincangan: } \\
\text { Subjek: } \\
\text { Manusia (1] Tokoh-tokoh berjasa; 2] lucah } \\
\text { atau terbuka aurat; 3] nabi-nabi; 4] para } \\
\text { sahabat 10 yang dijamin masuk syurga; 5] } \\
\text { Malaikat } \\
\text { Haiwan (Secara umum) } \\
\text { Tumbuhan dan pemandangan (Secara umum) } \\
\text { Bangunan dan peralatan (Secara umum) } \\
\text { Objek atau symbol yang melambangkan } \\
\text { agama bukan Islam } \\
\text { Gambar yang subjeknya menyalahi syariat } \\
\text { serta akhlak (Secara umum) } \\
\text { Gaya: Keseluruhannya } \\
\text { 1) } \\
\text { menggambarkan } \\
\text { gaya }\end{array}$ \\
\hline $\begin{array}{l}\text { Patung dan } \\
\text { Gambar } \\
\text { Menurut } \\
\text { Perspektif Islam }\end{array}$ & $\begin{array}{l}\text { Buku oleh } \\
\text { Salman } \\
\text { Maskuri } \\
(2007)\end{array}$ & $\begin{array}{c}\text { Mesir } \\
\text { (Pengaran } \\
\text { berasal dar } \\
\text { Malaysia) }\end{array}$ & $\begin{array}{l}\text { Membincangkan hal berkaitan patung dan } \\
\text { ggambar dari pelbagai pendangan ulama dari } \\
\text { i5 mazhab yang mahsyur iaitu mazhab Shafie, } \\
\text { Hanafi, Hambali, Maliki dan al-Dzahiri. } \\
\text { Perbincangan keseluruhan adalah dalam } \\
\text { kontek: } \\
\text { Subjek: } \\
\text { Patung: } \\
\text { patung yang disembah atau diagungkan; } \\
\text { patung bernyawa yang sempurna dan tidak }\end{array}$ \\
\hline
\end{tabular}




\begin{tabular}{|c|c|}
\hline & $\begin{array}{l}\text { diagungkan; } \\
\text { patung replica tidak bernyawa; } \\
\text { patung yang tidak sempurna; dan } \\
\text { 5) patung permainan kanak-kanak. } \\
\text { Gambar: } \\
\text { 1) Adalah tertumpu kepada gambar } \\
\text { bernyawa. Gaya: } \\
\text { 1) Keseluruhannya } \\
\text { menggambarkan } \\
\text { representasi }\end{array}$ \\
\hline $\begin{array}{lc}\text { Seni Menurut } & \text { Buku } \\
\text { Perspektif Islam (Terjemaha } & \text { n dari kitab } \\
\text { al- Islam wa } & \text { al- Fann, } \\
\text { 1996) oleh } \\
\text { Prof Dr } \\
\text { Yusuf al- } \\
\text { Qaradhawi } \\
(2001)\end{array}$ & 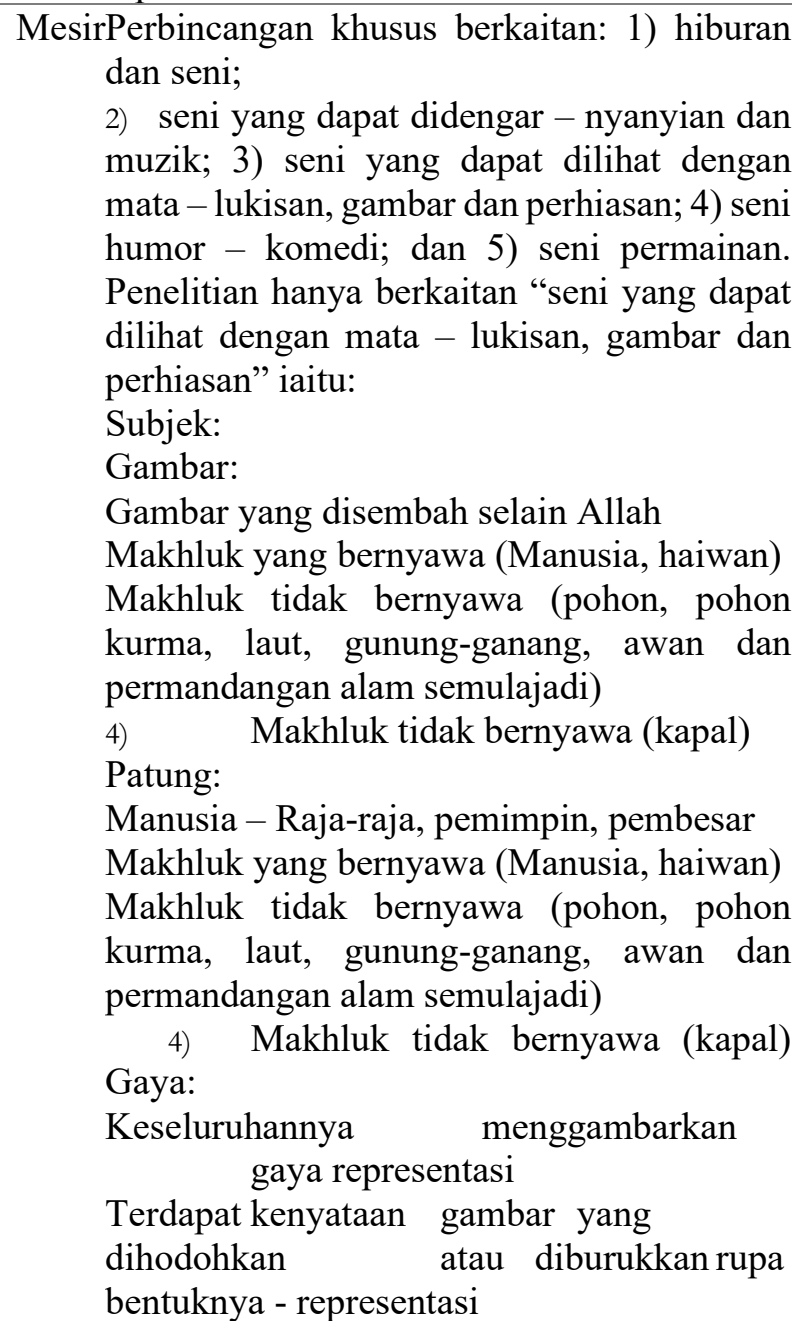 \\
\hline $\begin{array}{lc}\text { Fatwa Patung } & \text { Fatwa dari } \\
\text { yang terdapat di Pusat Fatwa } \\
\text { Muzium } & \text { Mesir } \\
& \text { (Salman, } \\
& \text { 2007) }\end{array}$ & $\begin{array}{l}\text { MesirHujah berkaitan hukum dan keperluan } \\
\text { perletakan patung didalam muzium. Secara } \\
\text { keseluruhan, keperluan pembinaan muzium } \\
\text { yang bermatlamat sebagai platform } \\
\text { mempamerkan dan mempelajari bahan } \\
\text { sejarah adalah dibenarkan (bukan untuk } \\
\text { diagungkan). Menyimpannya adalah tidak } \\
\text { ditegah, namun membuatnya semula adalah } \\
\text { ditegah termasuklah mempamerkan tubuh } \\
\text { manusia. Berikut subjek dan gaya dalam } \\
\text { perbincangan ini: } \\
\text { Subjek: } \\
\text { Manusia dan haiwan (patung, lukisan dan } \\
\text { ukiran di muzium) } \\
\text { Gaya: }\end{array}$ \\
\hline
\end{tabular}




\begin{tabular}{|c|c|c|c|c|}
\hline & & & $\begin{array}{l}\text { 1) } \\
\text { represen }\end{array}$ & $\begin{array}{l}\text { Keseluruhannya } \\
\text { menggambarkan gaya }\end{array}$ \\
\hline $\begin{array}{l}\text { Fatwa Patung } \\
\text { untuk } \\
\text { mempamerkan } \\
\text { Pakaian }\end{array}$ & $\begin{array}{l}\text { Fatwa Dr } \\
\text { 'Ammar } \\
\text { Ibrahim } \\
\text { Hassan } \\
\text { dalam } \\
\text { Manar al- } \\
\text { Islam } \\
\text { Salman, } \\
\text { 2007) }\end{array}$ & $\begin{array}{l}\text { Emiriah } \\
\text { Arab } \\
\text { Bersatu }\end{array}$ & \multicolumn{2}{|c|}{$\begin{array}{l}\text { penggunaan patung manusia yang sempurna } \\
\text { untuk mempamerkan pakaian. Namun } \\
\text { begitu, penjelasan untuk mempamerkan } \\
\text { pakaian boleh menggunakan patung yang } \\
\text { diubah bentuknya seperti dipotong kepala } \\
\text { atau dirungkai anggotanya sehingga hilang } \\
\text { bentuk asalnya. } \\
\text { Boleh jugamenggunakan patung yang sudah } \\
\text { dipatah- patahkan anggota utamanya. } \\
\text { Berikut perbincangan subjek dan gaya: } \\
\text { Subjek: } \\
\text { 1) Patung manusia sempurna Gaya: } \\
\text { 1) Keseluruhannya } \\
\text { representasi }\end{array}$} \\
\hline $\begin{array}{l}\text { Hukum } \\
\text { Gambar, } \\
\text { Patung dan } \\
\text { Lukisan } \\
\text { daripada Objek } \\
\text { Bernyawa }\end{array}$ & $\begin{array}{l}\text { Fatwa oleh } \\
\text { Mufti } \\
\text { Kerajaan } \\
\text { pada tahun } \\
2002 \\
\text { (Salman, } \\
2007 \text { ) }\end{array}$ & $\begin{array}{c}\text { Brunei } \\
\text { Darussalan }\end{array}$ & \multicolumn{2}{|c|}{$\begin{array}{l}\text { Penjelasan berkaitan penggunaan gambar } \\
\text { nfotografi dalam surat khabar yang dibaca } \\
\text { didalam masjid. Fatwa ini menerangkan } \\
\text { persoalan patung, gambar dari objek } \\
\text { bernyawa. Kedudukan fotografi adalah } \\
\text { berbeza dari kontek patung dan gambar } \\
\text { kerana teknik menahan bayangan objek dan } \\
\text { penggunaan bahan kimia. Berikut } \\
\text { perbincangan subjek dan gaya: } \\
\text { Subjek: } \\
\text { 1) Gambar bernyawa (Manusia, } \\
\text { haiwan) Gaya: } \\
\text { 1) Keseluruhannya } \\
\text { menggambarkan } \\
\text { gaya }\end{array}$} \\
\hline $\begin{array}{l}\text { Hukum } \\
\text { membuat } \\
\text { Gambar dan } \\
\text { menggantungny } \\
\text { a serta hukum } \\
\text { bergambar } \\
\text { dengan Video }\end{array}$ & $\begin{array}{c}\text { Fatwa oleh } \\
\text { Dr. } \\
\text { Abdullah } \\
\text { al- Faqih } \\
\text { pada tahun } \\
1999 \\
\text { (Salman, } \\
\text { 2007) }\end{array}$ & & \multicolumn{2}{|c|}{$\begin{array}{l}\text { Penelitian berdasarkan persoalan isu } \\
\text { menggantung fotografi berwarna dan hitam } \\
\text { putih dirumah, gambar yang dilukis dengan } \\
\text { tangan dan merakam gambar dengan video. } \\
\text { Hasilnya, penjelasan hukum terbahagi } \\
\text { kepada subjek dan gaya seperti berikut: } \\
\text { Subjek: } \\
\text { Gambar bernyawa (Manusia, haiwan) } \\
\text { Gambar tidak ada roh (pokok dan batu- } \\
\text { batu) } \\
\text { Gaya: Keseluruhannya } \\
\text { 1) menggambarkan } \\
\text { gaya } \\
\text { representasi }\end{array}$} \\
\hline
\end{tabular}

Hasil penelitian diatas, perbincangan fatwa dan garis panduan yang dilaksanakan dilihat berulang- ulang polanya dalam kategori subjek dan gaya dalam seni visual. Jadual ringkas yang dapat disimpulkan disini adalah seperti berikut: 


\begin{tabular}{|c|c|c|}
\hline $\begin{array}{l}\text { Kategori dalam } \\
\text { Seni Visual }\end{array}$ & $\begin{array}{c}\text { Sub-kategori } \\
\text { yang Dibincangkan }\end{array}$ & Pengklasifikasian \\
\hline \multirow[t]{6}{*}{ Subjek } & Manusia sempurna & Subjek Bernyawa \\
\hline & $\begin{array}{l}\text { Manusia yang dipotong atau } \\
\text { dihodohkan }\end{array}$ & Subjek Bernyawa \\
\hline & Haiwan & Subjek Bernyawa \\
\hline & $\begin{array}{l}\text { Gambaran/simbol/lambang yang } \\
\text { disembah } \\
\text { oleh agama lain }\end{array}$ & Simbol Agama \\
\hline & $\begin{array}{l}\text { Tumbuh-tumbuhan dan pemandangan } \\
\text { alam } \\
\text { semulajadi }\end{array}$ & Subjek Tidak Bernyawa \\
\hline & Peralatan ciptaan manusia & Subjek Tidak Bernyawa \\
\hline Gaya & Representasi & $\begin{array}{l}\text { Hampir keseluruhan perbincangan } \\
\text { menggambarkan subjek secara } \\
\text { representasi } \\
\text { Cadangan gambar dihodohkan atau } \\
\text { diurukkan rupa bentuknya }\end{array}$ \\
\hline
\end{tabular}

Oleh yang demikian, terdapat ruang untuk penambah-baikan dalam perbincangan hukum berkaitan subjek dan gaya dalam seni visual. Perbandingan yang jelas dapat dilihat dalam pendefinisian subjek dan gaya yang merangkumi beberapa aspek penting. Tiada perbincangan hukum, fatwa atau garis panduan yang menyatakan berkaitan subjek hybrid. Hal ini kemungkinan situasi tersebut masih belum berlaku semasa hukum dan fatwa diperbincangkan atau tiada persoalan yang diusulkan kepada jawatankuasa fatwa untuk dibincangkan. Selain itu, penjelasan keseluruhan fatwa dan garis panduan tertumpu pada gaya representasi semata-mata, sedangkan penghasilan karya seni adalah merangkumi gaya stailisasi dan abstraksi. Tiada penjelasan yang terperinci dalam membincangkan dua gaya yang penting ini.

\section{KESIMPULAN DAN CADANGAN}

Matlamat utama dalam penyelidikan ini iaitu dikhususkan berkaitan apakah jenis subjek dan gaya dalam seni visual yang telah dibincangkan dalam fatwa dan garis panduan yang telah wujud. Hasil daripada penelitian terhadap fatwa dan garis panduan yang telah wujud, penyelidik telah mengenalpasti beberapa jurang yang wujud dalam penyelidikan ini. jurang tersebut ialah: 1) penelitian semula persekitaran seni visual khususnya penggunaan subjek dan gaya dalam karya seni visual haruslah dilaksanakan; 2) dengan penelitian persekitaran seni visual, garis panduan dan fatwa yang sedia wujud memiliki ruang untuk ditambah baik.

Oleh yang demikian, penyelidik mencadangkan jurang yang telah diterangkan diatas haruslah diperhalusi semula dan kaedah kualitatif sebagai pendekatan yang paling sesuai dan tepat.

Dengan mengenalpasti situasi seni visual kontemporari di Malaysia, penyelidikan tersebut haruslah mendapatkan pandangan pakar seni visual berdasarkan proses temubual. Selepas itu, berdasarkan keputusan situasi seni visual yang telah dipersetujui pakar, penyelidikan haruslah diteruskan dengan menyediakan protokol temubual untuk pengumpulan data melalui pakar bidang Shariah Islam. Selain itu, penyelidik mencadangkan penyelidikan seni visual menurut pandangan Shariah Islam harus melihat dari kontek: 1) alat dan bahan yang digunakan dalam menghasilkan karya seni visual; dan 2) proses jual-beli artifak seni visual berdasarkan perjanjian dan prinsip pemilikan harta (seni visual) dalam Islam. Bidang ini dilihat masih tidak terdapat penyelidikan yang khusus dijalankan dalam skop seni visual.

Diharap, penyelidik yang berminat dengan penyelidikan ini dapat menggunakan perbincangan ini sebagai rujukan. 


\section{PENGHARGAAN}

Penyelidikan ini adalah diterbitkan melalui Geran Penyelidikan Fundamental (Fundamental Research Grant Scheme - FRGS) yang di taja oleh Kementerian Pendidikan Malaysia dan diuruskan oleh Pusat Pengurusan Penyelidikan (Research Menagement Center - RMC) Universiti Teknologi MARA; serta ditadbir oleh Unit Pengurusan Penyelidikan, Universiti Teknologi MARA Cawangan Perak dibawah no. rujukan 600-RMI/FRGS 5/3 (002/2017).

\section{RUJUKAN}

Abdul Azib Hussain, (2012). Manhaj Ilmu Fiqah \& Usul Fiqah. Kuala Lumpur: Telaga Biru Sdn. Bhd.

Ahmadrashidi Hasan, 2010a. Islam and Art. Kertas kerja telah dibentangkan di forum Art Talk, Fakulti Seni Lukis dan seni Reka, UiTM, Melaka.

Ahmadrashidi Hasan, 2010b. Contemporary Islamic Painting In Malaysia 1980 - 2000. PhD Thesis, Universiti Teknologi MARA, Malaysia.

Dzul Haimi Md Zain, (1997). Safavid Qur'ans: Style and Illumination. PhD Thesis, University of Edinburgh, Scotland.

Dzul Haimi Md Zain, (2003). Seni Islam. Selangor: Univision Press Sdn. Bhd.

Galeri Wei-Ling, (2015). The Space Between. Katalog Pameran di Galeri Wei-Ling dari 1 April - 1 Jun 2015.

Hanifah Musa Fathullah Harun \& Mashita Abu Hassan (2012). Pendapatan Halal Dalam Konteks Maqasid Shariah. e-Proceeding International Halal Conference 2012, PWTC, Kuala Lumpur.

Ishak Ramli, Mohamad Noorman Masrek \& Muhamad Abdul Aziz Ab. Gani, (in press). Visual Art from the Perspectives of Islamic Shariah. Journal of Advanced Science Letter.

Ishak Ramli, Mohd Daud A. Rahim, Mohd Faizul Noorizan, Ponirin Amin, Rahman Amin, \& Mohd Suhaimi Tohid, (2014). Seni Visual dan Permasalahannya: Satu Perkaitan dengan Konsep AdDharuriyyat dalam Maqasid Syariah. Proceeding World Conference on Islamic Thought, Casuarina@Meru Hotel, Perak

Ishak Ramli, Ponirin Amin, Rahman Amin, \& Mohd Suhaimi Tohid, (2012). Halal dan Seni Visual: Satu Hubungan dan Permasalahan di Malaysia. e-Proceeding International Halal Conference 2012, PWTC, Kuala Lumpur.

Jabatan Kemajuan Islam Malaysia, (n.d.). Garis Panduan dan Penjelasan Mengenai Seni Tampak dari Kaca Mata Islam. Retrieved on 1 September 2016, From Portal Jakim e-Fatwa. Website: http://www.e-fatwa.gov.my/

Khatijah Sanusi, (2000). Visual Art Education in Malaysia. Doctoral Dissertation, Temple University, USA.

Khatijah Sanusi, (2011). Era London: Sebelum dan Selepas. Raja'ah: Seni, Idea dan Kreativiti Sulaiman esa dari 1950-an - 2011. Kuala Lumpur: Balai Seni Visual Negara.

Muliyadi Mahamood, (1993). Kemekaran Jiwa Islam dalam Seni Lukis Malaysia Sezaman. Katalog Pameran Manifestasi Jiwa Islam dalam Senirupa Malaysia Sezaman: Balai Seni Lukis Negara.

Muliyadi Mahamood, (2001). Seni Lukis Moden Malaysia. Kuala Lumpur: Utusan Publication \& Distributors Sdn. Bhd.

Ocvirk, Stinson, Wigg, Bone, Cayton, (2009). Art Fundamentals Theory and Practice. Mc Graw Hill: School of Art, Bowling Green State University.

Osman Bakar, (1993). Kesenian Islam - Manifestasi Jiwa Islam dalam Kesenian. Exhibition Catalog, Festival Kesenian Islam, Istiqlal, Indonesia.

Sulaiman Esa, (1997). Islam and Politics of Art in Post-Independence Malaysia. Doctoral Dissertation, Temple University, USA.

Syamsul Anwar (1995), "Pandangan Islam Terhadap Kesenian”, cited from Jabrohim and Saudi Berlian (eds.), Islam dan Kesenian, Yogyakarta: Majelis Kebudayaan Muhammadiyah Universitas Ahmad Dahlan dan Lembaga Litbang PP Muhammadiyah, p. 204-206. 
Wan Samiati Adriana Wan Mohd Daud, (2013). Study on the Malaysian Islamic Visual Art: The Contemporary View. International Journal of Education and Research Vol. 1, No. 12, December 2013.

Yusuf Qaradhawi, (1989). Halal dan Haram dalam Islam. Singapura: Pustaka Nasional Pte Ltd. 